\title{
ILLNESS AND DEATH BEHIND THE WALLS OF THE CONVENT OF THE NORBERTINE SISTER IN IMBRAMOWICE IN THE LIGHT OF THE CHRONICLES OF SOPHIA GROTHÓWNA FROM THE YEARS 1703-1741
}

The Chronicle of Sophia Grothówna, abbes of the Imbramowice convent was written in the years 1703-1741 and published in print in 2011. The chronicles of the convent are a unique piece of literature which enables us to learn about the other aspects of monastic life than the relation with God and submission to the monastic rule. By analyzing these records we may discover other very important and interesting information. The chronicles of the convent in Imbramowice written by abbes Sophia include a plethora of captivating annotations concerning managing the convent and its farmstead but they also contain a number of information related to the everyday life of nuns. The chronicler devotes a significant part of her work to illnesses and deaths of sisters dwelling in the convent. These two inseparable facets of the life of every human surely could not elude a contemplative order.

As indicated on the pages of the chronicle treatment-related leaves outside the convent were rather frequent. It was so due to several factors. A maid inducted into the convent as a novice could already suffer from pre-existing conditions later exacerbated by harsh housing conditions in the convent. Not without the importance were the years when nuns had to relocate after a fire destroyed church buildings and harsh, damp and cold housing conditions in the new place of residence of nuns. Furthermore, the Dłubnia River flows through the domains of the convent which resulted in a humid environment in and outside the convent. In such conditions falling ill is not uncommon. Young maids, who were studying in the convent in Imbramowice, contending with harsh housing conditions in the convent, also fell ill.

To leave the convent an approval of the mother superior was required. Such requests were usually granted. A nun's leave for treatment, to Kraków or to one of healing resorts, was always costly, even more so due to the fact that nuns did not travel alone. Usually they travelled in threes in order to not embark on a return travel alone after taking the ill sister to Kraków. Therefore, if a sister did not have dowry money and the abbes could not allocate appropriate funds for her treatment a cyrulik (a barber-surgeon) ${ }^{1}$ was brought in to provide first aid. A barber-surgeon also expected payment but it was a smaller sum. Abbes

\footnotetext{
* Translated by Spektra Sp. z o.o.

Cyrulik (a barber-surgeon) - is a corrupted form of a word surgeon, his main occupation was shaving, extracting teeth, blood drawing and simple surgeries, services of a barber-surgeon were often called upon because they were significantly less expensive, see B. Ogrodowska, Medycyna tradycyjna w dawnej Polsce, Warszawa 2012, pp. 55-57.
} 
Grothówna noted that her leave to Silesia was financed by various benefactors. The costs were significant because sister left with two other nuns for a period of a month and a half ${ }^{2}$. The second leave, as she noted, was financed from her own dowered money ${ }^{3}$. Leaves for treatment were also financed by Fr. Dominik Lochman.

The most frequently recorded treatment leaves are of abbes Grothówna who was, as noted on the pages of the Chronicle, a very sickly person. Due to her station within the convent it was a major problem. The convent chronicler recorded that in 1722 abbes suffered from a fever lasting two days and after that she felt great discomfort in her right leg, as the right leg swollen greatly and grew livid 4 . Grothówna also experienced „pressure in her rightflank." She often felt ill and was plagued by fevers and skin inflammation. However, the most severe illness which directly led to death of the abbes was the disease of eyes. The abbes wished to start treatment but was unable to arrange for an appointment with a doctor who wanted to examine the sick. She waited for him five weeks travelling to meet him. Swelling irritating the leg went up and abbes knew that she was dying ${ }^{6}$.

Although the names or descriptors of the illnesses/ailments were usually noted the convent chronicle presents very little details concerning the diseases plaguing nuns. And therefore sisters were suffering from puchlina $[t n-s w e l l i n g]^{7}$, headaches and sore throat treated with ,plastry [tn-plasters]” or ,sprycowanie [tn -spirting]”, dyspnea and consumption or „maligna [tn-malignant fever]"8. Ailments relating to stomach and legs were also recorded. Ailments of muscles or various pains were treated by rubbing the afflicted part of the body with vodka to warm up the ailing area. Often blood drawing was used as a universal panacea for all maladies, from headaches to stomach pains. It is recorded in several places in the chronicle that commonly a barber-surgeon was called in to perform the procedure. The chronicle mentions mister Pączkowski with the greatest frequency. Other remedy for a numerous ailments was vacuum cupping. This in turn was the responsibility of a łaziebnik $[t n \text { - bath-keeper }]^{9}$ summoned by Grothówna. The convent was also visited by sisters of Mercy $^{10}$. Nuns from the Imbramowicki convent also made use of „various medicines” from pharmacy in Kraków which were sent over by the convent superiors or a commissioner. Sister Elżbieta Górska for many years suffered from mental illness which must have manifested after the profession of religious vows because she suffered from numerous incursio $[\text { tn }- \text { fits }]^{11}$

\footnotetext{
2 Z. Grothówna, Kronika klasztorna sióstr norbertanek Imbramowicach 1703-1741, Kielce 2011, pp. $126-127$.

3 Ibidem, p. 149.

4 Ibidem, p. 152.

Ibidem, p. 169.

6 Ibidem, p. 255.

7 puchlina (swelling) - old Polish name for oedema, not used anymore in modern medicine. Oedema - accumulation of fluids below skin may be the result of liver and kidney diseases, heart failure or septicemia, see A Szczeklik (editor.), Choroby wewnętrzne, Kraków 2005, pp. 16-17.

8 Malignus - Latin for malignant; malignant fever accompanied by hallucinations.

9 Łaziebnik (a bath-keeper) - in XVIII bath-keepers were forbidden to treat the ill, their duties were mainly shaving and preparing baths but they also could perform vacuum cupping, see Ibidem, p. 58.

10 Sisters of Mercy, commonly referred to as „Szarytki” (sisters of Charity) - nuns obliged to help the sick by establishing and managing hospitals, visiting the sick at home and collecting money for the sick, see A. Dzierżak, S. Motyka, W. Bomba, J. Dukała, Zgromadzenie Sióstr Miłosierdzia św. Wincentego a Paulo w Polsce (1652-2002), Kraków 2002, pp. 9-18.

11 Incursio - a Latin term meaning a fit.
} 
and devilish temptations so potent that she even sometimes cursed and reviled God ${ }^{12}$. In the critical moment, just before her death, she regained lucidity and was able to receive the Anointing of the Sick rite ${ }^{13}$.

To recuperate nuns travelled mainly to the Norbertine convent in Zwierzyniec, St. Joesph's convent of St. Bernard Sisters and St. Andrew's convent of Poor Clares in Kraków. The length of the visits varied and was usually dependant on nun's condition but rarely exceeded one month. Sisters staying in Kraków were under the care of an on-site doctor and a barbersurgeon who not always had time to come to and stay in the convent in Imbramowice for a prolonged period of time (usually they came for a rather brief visit, a few hours) due to the needs of the other sick.

Abbes Grothówna herself made several trips in company of two nuns to „Landeckie waters”, the contemporary Lądek-Zdrój in Silesia and to „Krzeszowskie waters” near Rudawa (which at that time were a property of Fr. Lochman). The abbes' leaves lasted between two weeks and two months. In turn, sister Modrzewska was granted a permission to go to her family in the Pogórze area to recuperate ${ }^{14}$.

The decision to call for a doctor or a barber-surgeon was made based on the condition of a nun. When sister Lewikowska suffered from swelling [...] a doctor was brought for comfort. The same day she received holy sacraments and waited for God to will her fate ${ }^{15}$. A doctor was called for and arrived after several days but her condition must have been severe because she died ten weeks later in the infirmary of the convent ${ }^{16}$. An extreme, critical condition cases also occurred. Sister Pajęcka [...] having her knee swollen greatly was suffering unbearable pain when a barber-surgeons was cutting it $[\ldots . .]^{17}$. Other nun, Anna Gołębiowska, after falling down the stairs bruised her leg so much that she also required the help of a barber-surgeon. A barber-surgeon also had to visit sister Magdalena Zaleska who had an ailing leg because wounds have opened on the limb ${ }^{18}$.

Therefore the health of nuns and their problems with skeletal system were probably rheumatic in nature due to, i.a. cold and damp rooms and chambers.

Health problems and death, as the inevitable elements of human life, were recorded in the chronicle. On the following pages of the records we can read dramatic descriptions of the agony of nuns, i.e. sister Śliwska who during the prayer fell down struck with paralysis, mute, deaf and blind, left without senses, only breathing and able to move one hand ${ }^{19}$. Despite the intervention of a doctor the nun died three days later suffering and in pain ${ }^{20}$. Sister Zofia Żuchowska died after fourteen weeks of severe illness. By the end worms feasted on her flesh before she died ${ }^{21}$. Other nun, Sister Katarzyna Suleńska, who lost her sight 10 years prior, locked herself in her cell for the night. In the morning, when she did not arrived for prayers

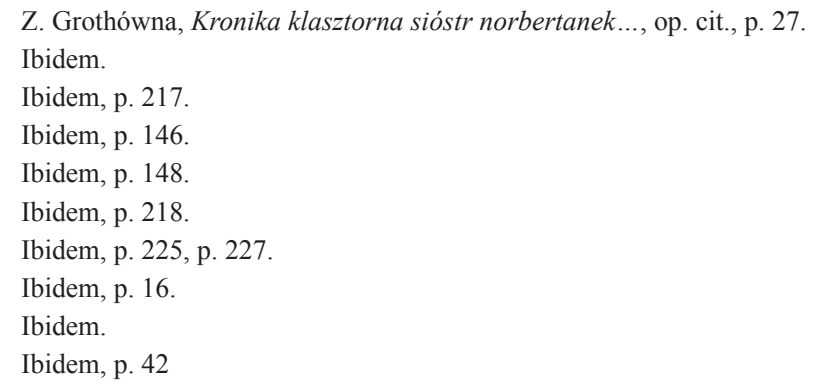


and [she] did not respond to knocking at her door through the keyhole [I] saw her lying in bed and I told [abbes] to get the ladder and enter through the window ${ }^{22}$. The nun was still alive but there was nothing to be done and she died after three hours ${ }^{23}$.

The death of Abbes Sophia Grothówna was similarly horrid and painful. Pain in her leg must have been very cumbersome and she suspected she was dying. She received the Anointing of the Sick and died. Despite the fact that at the time of death abbes was staying in Kazimierza Mała funeral took place three days later. Body was not presented for long due to the heat wave. Funeral mass was celebrated in Kazimierza and nuns from Imbramowice were chanting vigils. On the day of funeral two High Masses were celebrated, numerous priests and monks were present as well as approximately 50 paupers who were customary fed after the funeral concluded. Furthermore, alms were sent to the poorest monasteries in Kraków. Thirteen days after the death of the abbes exequies were celebrated. As it was recorded - a new casket was prepared for Grothówna [...] finished in white and standing on three white grades. Around the casket there were twelve large candles... six torches were being held and six more torches were burning between candles behind the great altar. There were thirteen of us, nuns inducted by the dearly departed benefactress into the convent, kneeling beside the casket and holding candles[...] An enormous number of priest (90!) gathered for the exequies during the funeral of the abbes. Mass was presided over by the abbot of Norbertine monks from Nowy Sącz and overseer of the Polish region. Nuns prepared a meal for 300 poor faithful. Masses with the intention of the departed abbes were held 15 and 40 days after her death ${ }^{24}$.

Funerals were usually held within three days of death ${ }^{25}$. In case of choir maidens or lay sister usually a few priests and monks from different monasteries participated in the rites. A mass was celebrated in the church because nuns were laid to rest in a crypt below the church erected during the governance of abbes Grothówna, as early as in 1712, before the church building was completed. It is difficult to explicitly ascertain whether an orchestra was present during all funerals. The Chronicle mentions only one such instance, during the funeral of Anna Postupalska.

On the pages of the chronicle abbes Grothówna recorded an extraordinary ceremony, funeral of the previous mother superior. Sister Krystyna Oraczowska, former abbes of the convent in Imbramowice, resided in the convent in Zwierzyniec after the fire. She did not return to Imbramowice due to convent's meager financial standing and her own illness. She died in Zwierzyniec convent on the 11th of October 1712. In the chronicle Abbes Grothówna described burial rites in detail. Services were held in Zwierzyniec because local nuns wished to bury former abbes in their convent despite the fact that sister Oraczowska was the mother superior of the convent in Imbramowice. Therefore nuns from Imbramowice, primarily Sophia Grothówna, requested the return of the body of the departed. This resulted in a major dispute. The convent in Imbramowice had primacy. It was here where Krystyna Oraczowska held the highest monastic office and this is why Fr. Dominik Lochman demanded the release of the body. Nuns from Zwierzyniec seemed to be convinced until the end that the body of the

\footnotetext{
22 Ibidem, p. 105

23 Ibidem.

24 Ibidem, p. 255-256.

25 Only Anna Postupalska was buried eight days after her death, no reasons were given why, see Ibidem, p. 255.
} 
departed will be buried in their convent because after the burial rites a grave was prepared. However, due to the insistent efforts of Fr. Lochman after the ceremony casket was moved out and transported to Imbramowice. Along the road leading through Skała priests were riding beside the casket. Bells were rung in celebration, also after the arrival at St. Benedict Abbot parish church in Imbramowice. Local populace gradually gathered around the funeral procession to participate in the funeral rites of the former abbes from Imbramowice. Later several priests stepped onto the road and after laying the body on mary [tn-hearse ${ }^{26}$ participants of the procession sung and the body was laid to rest in the church ${ }^{27}$. On the following day several plainsong masses were celebrated with the intention of the departed. Thirty priests and monks from Hebdów came. Later a prelate dressed in cape, monks and local people saw the departed off to the chapel. Norbertine sisters from Imbramowice met them solemnly taking positions on both sides of the wicket and holding candles ${ }^{28}$. Nuns seized casket from priests and moved it to the wooden chapel. Sister Oraczowska died two years after the complete destruction of the convent buildings. Nuns adorned the chapel with black linen and candles; hearse was placed in the middle of the room. [...] after that, according to the custom, command was sung and after that a plainsong High Mass was celebrated. After the mass wiljie $[t n-v i g i l s]^{29}$ were sung by priests. Later solemn sum with stations was held and after that the funeral procession formed and we once again, holding candles, took place in front of the chapel and moved body from the church to the grave[...]. After the conclusion of funeral rites abbes Grothówna prepared a dinner for all present, priest and people alike. The entirety of the funeral was paid for by the convent in Imbramowice ${ }^{30}$.

It was a frequent custom to invite paupers for a meal and to hand out charity after the conclusion of a funeral ceremony. The mother superior of the convent in Imbramowice did so after the death of Krystyna Oraczowska: for the salvation of her soul she brought in 24 paupers who, after participation in the mass, could eat a meal in the courtyard of the convent and received charity. There was also a custom of singing vigils and commands ${ }^{31}$ one day after someone's death. Also, according to the custom of the convent, thirty days after death vigils with a command and a High Mass were celebrated along with a dinner for paupers of whom 46 arrived $^{32}$. Furthermore, masses with the intention of the departed nuns of the convent were celebrated for a year after their deaths.

It is hard to ascertain the age of death of nuns. Years were not noted in the majority of cases but sometimes a chronicler recorded the age of the departed. The information in the chronicle indicates that the oldest departed was abbes Franciszka Siemieńska who was 82 years of age, and has stayed with the convent for 68 years. Sister Barbara Dębińska was 80 years old when she died, nun Katarzyna Suleńska died at 70 and was a member of the convent for 52 years. In contrast, Krystyna Rapstyńska was 54 years old when she died, similarly to

\footnotetext{
26 mary (a hearse) - a form of a stretcher used to move the departed to the grave, Z. Gloger, Encyklopedia staropolska, vol. 3, Warszawa 1989, p. 191.

27 Z. Grothówna, Kronika klasztorna sióstr norbertanek ..., op. cit., p. 60.

28 After the destruction of the convent buildings nuns were not formally bound by the monastic rule and could leave without permission.

${ }^{29}$ wilje (Vigils) (Latin - Willie) - a wake

30 Z. Grothówna, Kronika klasztorna sióstr norbertanek..., op. cit., pp. 59-61.

31 Ibidem.

32 Ibidem, p. 62.
} 
Katarzyna Misiowska. Abbes noted that she has been a nun for 30 years. Only a brief note was made about Konstancja Lisińska - she lived in the convent for 45 years $^{33}$ and therefore must have been at least approximately 60 years old.

Confessors who died in the convent in Imbramowice were also buried in the church. Instances of lay-people being buried in the convent church were also recorded. One of such people was a divorcee, madam Teresa Kamodzińska, whose family donated three thousand from the Raszków village (former Włoszowski poviat) in exchange for celebrating masses with the intention of the departed on certain Tuesdays and Fridays. Furthermore, nuns were to conclude each Friday morning prayer with the words: Qui passus es pro nobis. Jesu Christe misere nobis ${ }^{34}$. Agnieszka Zakrzewska from Ściborzyce, a benefactress of the convent, was also buried in the church and her body was laid to rest in the same place as other nuns ${ }^{35}$. The convent also became the resting place of Katarzyna Grothówna, a student who after the conclusion of the education in the convent, went back home but five weeks later fell ill and died of pox $^{36}$. The last lay-person buried in the convent during the governance of Sophia Grothówna was Anna Grothówna, 70 years old and constantly fasting and mortifying herself. Mother superior financed the funeral using convent funds and invited and regaled 15 paupers to compensate for the sins of the departed ${ }^{37}$.

The Chronicle also includes information concerning a burial of the heart of Dorota Gębicka nee. Grothówna, the wife of the starost [tn-governor] of Nakło, in 1733. Three days after her death her body was laid to rest in the church of the Reformed Fathers in Kraków and her heart was placed a in special marble tombstone beside the altar of Blessed Virgin Mary. Family of the departed gifted the convent with a supply of candles for three years and a large number of funereal linens ${ }^{38}$. Another unusual event described in the chronicle was recorded toward its end. After the parish church burned down in 1732 and was rebuild four years later a funeral and burial of bones took place. It was a rather modest ceremony celebrated jointly with consecration of the new church ${ }^{39}$. Therefore it was most likely a „repeated” burial during which bones were laid to rest in a so called ossarium.

The chronicle also includes records of the deaths of local peasants and craftsmen rebuilding the church. And so abbes recorded the death of a bailiff from Zagórowa who was digging up clay. Unfortunately soil slid and he was completely buried. Mother superior funded his funeral with the convent money and laid him to rest in the parish church ${ }^{40}$. Three masons also died while building the church. Abbes organized a funeral for each of them and buried them in the parish church.

\footnotetext{
3 Ibidem, pages 89, 26, 104, 28, 85, 227.

34 Translation: Jesus Christ, You who died for us, have mercy upon us; Z. Grothówna, Kronika klasz-torna sióstr norbertanek..., op. cit., p. 28.

35 Ibidem, p. 131.

36 Ibidem, p. 109.

37 Ibidem, p. 245.

38 Ibidem, p. 326

39 Ibidem, p.242.

$40 \quad$ Ibidem, p. 67.
} 
Masses were also celebrated with the intentions of benefactors and superiors of the convent. For instance with the intention of Marcin Węgrzynowicz ${ }^{41}$, canon of Cracow, and Andrzej Węgrzynowicz ${ }^{42}$, bishop of Łubień or Kacper Bażanka, the architect who designed the convent buildings. A year after the death of Agnieszka Zakrzewska two masses were celebrated with the intention of the departed ${ }^{43}$. Abbes Grothówna prayed along with the entirety of the convent for her sister Aniela Grothówna, a nun in St. Josephs convent of the St. Bernadine Sisters in Kraków ${ }^{44}$.

Table no. 1 Nuns staying in the convent in Imbramowice during the governance of Abbes Sophia Grothówna in 1703-1741.

\begin{tabular}{|c|c|c|c|c|}
\hline Nun & Novice & Perpetual function & Station in the convent & Date of deth \\
\hline Franciszka Siemieńska & 1652 & 1653 & Choir sister/ abbes & April 24th, 1716 \\
\hline Krystyna Oraczowska ${ }^{A}$ & 1653 & 1654 & $\begin{array}{c}\text { Choir sister/ abbes } \\
1688-1703\end{array}$ & October 11th, 1712 \\
\hline Katarzyna Suleńska ${ }^{B}$ & 1653 & 1654 & $\begin{array}{l}\text { Choir sister/ } \\
\text { Cantor }\end{array}$ & August 4th, 1712 \\
\hline Barbara Dembińska & 1663 & 1664 & Lay sister & April 4th, 1707 \\
\hline Krystyna Rabaszyńska & 1674 & 1676 & Choir sister/ Circatrix & July 29th, 1707 \\
\hline $\begin{array}{l}\text { Elżbieta Aleksandra } \\
\text { Górska }\end{array}$ & 1674 & 1676 & Choir sister & May 14th, 1707 \\
\hline $\begin{array}{l}\text { Helena Magdalena } \\
\text { Lewikowska }\end{array}$ & 1678 & 1680 & $\begin{array}{c}\text { Choir sister/ mistress of lay } \\
\text { sisters }\end{array}$ & June 22nd, 1722 \\
\hline $\begin{array}{l}\text { Agnieszka Helena } \\
\text { Słomińska }\end{array}$ & 1678 & 1681 & Choir sister/ sacristian & March 9th, 1743 \\
\hline Jadwiga Śliwska & 1685 & 1687 & Choir sister/ novice mistress & December 12th, 1705 \\
\hline $\begin{array}{l}\text { Konstancja Ludmiła } \\
\text { Lisińska }\end{array}$ & 1685 & 1687 & $\begin{array}{c}\text { Choir sister/dispensatrix, } \\
\text { receptionist }\end{array}$ & March 23rd, 1730 \\
\hline Katarzyna Misiowska $^{\mathrm{C}}$ & 1687 & 1688 & Choir sister & January 21st, 1716 \\
\hline $\begin{array}{l}\text { Zofia Magdalena } \\
\text { Krajowska }\end{array}$ & 1688 & 1691 & Choir sister & April 17th, 1729 \\
\hline $\begin{array}{l}\text { Marianna } \\
\text { Modrzejowska }^{\mathrm{D}}\end{array}$ & 1690 & 1692 & $\begin{array}{c}\text { Choir sister/ secretary, } \\
\text { abbes }\end{array}$ & November 23rd, 1745 \\
\hline Zofia Żuchowska & 1690 & 1692 & Choir sister & May 15 th, 1710 \\
\hline Teresa Majerówna & 1691 & 1692 & Choir sister/ sub-cantor & $\begin{array}{c}\text { October 6th } 1765 \\
\text { (105 years old) }\end{array}$ \\
\hline Zofia Grothówna & 1691 & 1694 & Choir sister/Abbes & May 31st 1741 \\
\hline
\end{tabular}

${ }^{41}$ Fr. Marcin Wegrzynowicz - canon of Cracow, custodian of Kielce, canon of Płock, archdeacon of Piła, parish priest in Tczyca, L. Łętowski Katalog biskupów, pratatów i kanoników krakowskich, vol. 4, Kraków 1853, p. 213. 42 Fr. Andrzej Węgrzynowicz - doctor of both laws, canon of the parish in Kunica, custodian of Sandomierz, canon of Cracow and Kielce, died in 1727, L. Lętowski, Katalog biskupów, prałatów i kanoników krakowskich, op. cit.., p. 213.

${ }_{43}$ Z. Grothówna, Kronika klasztorna sióstr norbertanek..., op. cit., pp. 141.

44 Sister Aniela (Marianna) Grothówna - a nun in St. Joseph's convent of St. Bernard sisters, entered novice in 1701, stayed in Imbramowice in 1723, died on May 1st 1727, M. Borkowska, Leksykon zakonnic polskich epoki przedrozbiorowej, Polska Centralna i Poludniowa, vol. 2, Warszawa 2005, p. 219. 


\begin{tabular}{|c|c|c|c|c|}
\hline Nun & Novice & Perpetual function & Station in the convent & Date of deth \\
\hline Anna Gołębiowska & 1693 & $?$ & $\begin{array}{c}\text { Choir sister/keeper of the } \\
\text { refectory, abbes }\end{array}$ & October 13th(?) 1741 \\
\hline Teresa Reklowska ${ }^{\mathrm{E}}$ & 1698 & 1699 & $\begin{array}{l}\text { Choir sister/nurse } \\
\text { circatoress }\end{array}$ & December 28th 1746 \\
\hline Anna Katarzyna Rodecka & 1698 & 1699 & Choir sister/ receptionist & April 26th 1746 \\
\hline Anna Postupalska & July 26th 1707 & 1709 & $\begin{array}{l}\text { Choir sister/ cantor and } \\
\text { spiritual leader }\end{array}$ & May 11th 1741 \\
\hline Jadwiga Majerówna & $\begin{array}{c}\text { 13th October } \\
1707\end{array}$ & 1709 & Choir sister/ sub-cantor & March 1st 1767 \\
\hline Zofia Stoińska ${ }^{\mathrm{F}}$ & 1709 & $\begin{array}{l}\text { May 21st } 1717 \\
\text { resigned }\end{array}$ & Choir sister & - \\
\hline Justyna Otfinowska & - & - & Novice & March 29th 1711 \\
\hline Anna Kochanowska & $\begin{array}{c}\text { August 29th } \\
1717\end{array}$ & $\begin{array}{c}\text { September 3rd } \\
1718\end{array}$ & $\begin{array}{c}\text { Choir sister/mistress of lay } \\
\text { sisters }\end{array}$ & November 23rd 1761 \\
\hline Teresa Wietrzyńska & $\begin{array}{c}\text { August 29th } \\
1717\end{array}$ & January 29th 1719 & Lay sister/choir sister & January loth 1765 \\
\hline Teresa Zagrodzka & $\begin{array}{c}\text { August 29th } \\
1717 \\
\end{array}$ & January 29th 1719 & Lay sister & June 1st 1747 \\
\hline Weronika Fazerówna & $\begin{array}{c}\text { September 3rd } \\
1718\end{array}$ & October 29th 1719 & $\begin{array}{c}\text { Choir sister/ basement } \\
\text { keeper }\end{array}$ & December 9th 1755 \\
\hline Anna Pajęcka ${ }^{\mathrm{G}}$ & $\begin{array}{c}\text { January 28th } \\
1720\end{array}$ & February 16th 1721 & Choir sister/ nurse & August 26th 1771 \\
\hline Barbara Grothówna & $\begin{array}{c}\text { January 28th } \\
1720\end{array}$ & February 16th 1721 & $\begin{array}{c}\text { Choir sister/ keeper of the } \\
\text { refectory }\end{array}$ & October 8th 1749 \\
\hline Magdalena Zalejska $^{\mathrm{H}}$ & $\begin{array}{l}\text { August } 7 \text { th } \\
1720\end{array}$ & August 7th 1721 & Choir sister/dispenser & May 7th 1737 \\
\hline Katarzyna Bąkowska ${ }^{\mathrm{I}}$ & May 17th 1723 & April 9th 1725 & Choir sister/ sub-sacristan & May 2nd \\
\hline $\begin{array}{l}\text { Teresa Anna } \\
\text { Miroszewska }^{\mathrm{J}}\end{array}$ & $\begin{array}{l}\text { November } \\
25 \text { th } 1725\end{array}$ & March 30th 1727 & Choir sister & July 2nd 1769 \\
\hline Salomea Bogucka ${ }^{\mathrm{K}}$ & June 11th 1726 & June 24th 1728 & Choir sister & December 12 th 1767 \\
\hline Teresa Chwalibożanka & $\begin{array}{c}\text { October } 25 \text { th } \\
1727\end{array}$ & $\begin{array}{c}\text { November 21st } \\
1729\end{array}$ & Choir sister & December 17th 1788 \\
\hline Józefa Urbańska & July 5th 1730 & March 4th 1731 & Choir sister & April 11th 1790 \\
\hline Helena Łękawska & $\begin{array}{c}\text { February } 7 \text { th } \\
1738\end{array}$ & 1739 & Choir sister & June 1st 1778 \\
\hline Katarzyna Nakielska & 1739 & October 30th 1740 & Choir sister & February 17th 1758 \\
\hline Elżbieta Tokarska ${ }^{\mathrm{L}}$ & June 1st 1740 & 1741 & Choir sister & July 30th 1785 \\
\hline Katarzyna Grothówna & July 6th 1740 & 1741 & Choir sister & February 17th 1758 \\
\hline $\begin{array}{l}\text { Agnieszka Felicjanna } \\
\text { Otwinowska }\end{array}$ & $\begin{array}{c}\text { August 25th } \\
1741\end{array}$ & 1742 & Choir sister & July 30th 1785 \\
\hline
\end{tabular}




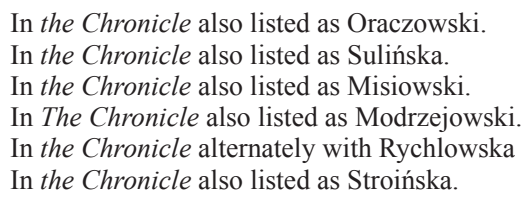

In the Chronicle also listed as Oraczowski. In the Chronicle also listed as Sulińska. In the Chronicle also listed as Misiowski. In The Chronicle also listed as Modrzejowski. In the Chronicle alternately with Rychlowska In the Chronicle also listed as Stroińska.

G In the Chronicle alternately with Pajęcki spelling.

In the Chronicle also listed as Zaleska.

In the Chronicle alternately with Bąkowski.

In the Chronicle also listed as Miraszewska.

In the Chronicle alternately with Bogucki.

In the Chronicle also listed as Tokarski.

The table presents nuns staying in the convent in Imbramowice between 1703 and 1741 . In total there were 40 nuns during the period of the governance of abbes Grothówna. If a maiden hailed from nobility she would become a choir sister, if not - a lay sister. Choir sisters held higher positions in the hierarchy of the convent. In Imbramowice the majority of maids came from the noble houses. In one instance abbes Grtothówna elevated Teresa Wietrzyńska to a position of a choir sister in recognition of her merits and hard work for the benefit of the convent. Maidens entered the convent at different age, usually before the attaining the age of 21. However, establishing precise age bracket on the basis of the 1703-1741 chronicles is impossible. After entering into the novitiate maidens spent approximately two years preparing to take vows. After that they spend their lives in the retreat of the convent holding positions appointed by the abbes. Sister Magdalena Zalejska spent the shortest period of time in the convent - 17 years, sister Teresa Majerówna stayed with the convent for the longest period -74 years (she died at the age of 105). The average age of nuns from Imbramowice between 1703 and 1741 was 42 years.

\section{Illness and death behind the walls of the convent of the Norbertine in Ibramowice in the light of the Chronicles of Sophia Grothówna from the years 1703-1741 Summary}

The article describes illness and death behind the walls of the convent of the Norbertine in Ibramowice in light of The Chronicle Sophia Grothówna from the years 1703-1741. Health problems and death in human life are two inevitable events. As a people we know this is unavoidable and we will meet every existence. Sisters of Mary also were afflicted with minor or major health problems. The nuns lived in damp conditions. At the monastery Imbramowice flows flows the river Dłubnia, causing a humid environment. Nuns in Imbramowice had to contend with difficult housing conditions after a fire in 1710. Norbertine's coped with the diseases in various ways:leaving for treatment to spas (with the consent of the bishop and the abbess), or waiting for assistance of a barber, doctors came less frequently. The article contains also diseases to which the sisters suffered. In the second part, the paper describes the death of sisters and everything that is associated with it. Every act of dying featured in the pages of The Chronicle abbes Grothówna was dramatic. After the death of a Norbertine followed by a funeral, if the nun exercised a high function at the monastery burial was very solemn and distinguished guests arrived. The Sisters of Mary also organized refreshments for the poor people, to help the dead and prayed for a specified period of time. The article includes a list of all the sisters residing at the monastery in Imbramowice over the years 1703-1741. The table presents information: date of commencement of the novitiate, professed, perpetual function each nun and date of death. 
Keywords: The monastery, Norbertine, Imbramowice, nuns, death, illness

About the author: Milena Mierzejska was in years 2009-2014 a student of history at The Cardinal Wyszyński University in Warsaw. Currently she is a postgraduate at the same university. She started her postgraduate course in 2014. She is interested in history of the Church, particularly in the history of the enclosed female convents. She conducts her research on Benedictine sisters in Sieprce, formerly on Norbertine sisters in Imbramowice. 